\title{
THE EUROPEAN UNION'S POLICY TOWARDS ITS EASTERN NEIGHBOURS: THE CRISIS IN UKRAINE ${ }^{1}$
}

\author{
Tatsiana Shaban \\ University of Victoria
}

\begin{abstract}
The European Union's neighbourhood is complex and still far from being stable. In Ukraine, significant progress has occurred in many areas of transition; however, much work remains to be done, especially in the field of regional development and governance, where many legacies of the Soviet model remain. At the crossroads between East and West, Ukraine presents an interesting case of policy development as an expression of European Union (EU) external governance. This paper asks the question: why was the relationship between the EU and Ukraine fairly unsuccessful at promoting stability in the region and in Ukraine? What was missing in the European Neighbourhood Policy (ENP) in Ukraine that rendered the EU unable to prevent a conflict on the ground? By identifying security, territorial, and institutional challenges and opportunities the EU has faced in Ukraine, this paper underlines the most important factors accounting for the performance of its external governance and crisis management in Ukraine.
\end{abstract}

\footnotetext{
${ }^{1}$ An earlier version of this paper was presented at the "Multiple Crises in the EU" CETD conference at University of Victoria, Feb 23rd, 2017. This conference was made possible by generous financial support from the CanadaEurope Transatlantic Dialogue at Carleton University. The author would like to acknowledge Amy Verdun, Zoey Verdun, Valerie D'Erman, Derek Fraser, and two anonymous reviewers of this journal for their comments on earlier drafts of this work. The author thanks Emmanuel Brunet-Jailly (and the Borders in Globalization project) for continued support. Special thanks to Joan DeBardeleben, the Editor-in-Chief of this journal for helpful comments and continued encouragement. Funding was provided by Social Sciences and Humanities Research Council of Canada, by a grant through Dr. Amy Verdun.
} 


\section{Introduction}

Ukraine signed the Charter on a Distinctive Partnership with the North Atlantic Treaty Organisation (NATO) in 1997. In doing so, it effectively self-identified as a 'European' state, in the sense of pledging allegiance to this important Western security alliance. A year later, Ukraine established its European foreign policy course when the Partnership and Cooperation Agreement (PCA) between the European Union (EU) and Ukraine came into force. ${ }^{2}$ In 2010 , the Ukrainian Parliament adopted the law "On the principles of foreign and domestic policy," which further prioritised integration into the EU, with the aim of acquiring membership (The Law of Ukraine №2411-VI of 01.07.2010). However, the crisis in Ukraine in February 2014 clearly demonstrated that the EU will have to develop a different strategic approach in its policy toward its Eastern neighbours in order to stabilize the situation in the region. People protested against the government of then-President Viktor Yanukovych, who had concentrated enormous assets within his own family and found himself in a vulnerable position manoeuvring between Russia and the EU. On 22 February 2014, the Ukrainian parliament (Verkhovna Rada or just Rada) voted Yanukovych out of power after he refused to sign the Association Agreement (AA) with the EU and turned to Russia, instead. Likewise, the Rada announced new presidential elections for 25 May of that same year. In the end, the Maidan revolution (also known as the "Revolution of Dignity") produced a prolonged political, economic, and security crisis in Ukraine, regionally and internationally. ${ }^{3}$

This paper asks the question of why the relationship between the EU and Ukraine was fairly unsuccessful at promoting stability in the region and in Ukraine. What was missing in the European Neighbourhood Policy (ENP) policy in Ukraine that rendered the EU unable to prevent a conflict on the ground? To answer this, this paper proceeds in four steps. First, it provides a brief literature review of recent academic debates on Europeanisation and EU governance, which have paid extensive attention to the development of the ENP and the Eastern Partnership (EaP). Scholarly debates provide a conceptual framework for the EU as a transformative power and help understand the EU's external performance in promoting stability in the region. Second, the paper examines the relationship of the EU and Ukraine by examining the progress of the ENP and development of its specific programs and instruments in the area of security and regional integration. Third, it analyses territorial and security challenges the EU encountered on the ground, including the role of NATO and Russia in the Ukraine crisis. Finally, it explores institutional opportunities for EUUkraine cooperation. This paper only covers the period of the ENP between the implementation of the EaP policy, launched by the EU in 2009 on the initiative of Sweden and Poland, and its second revision in November 2015. ${ }^{4}$ That period has been marked by an escalating confrontation between the EU and Russia based on disagreement about the EaP's goals and functions. The

\footnotetext{
${ }^{2}$ The PCA between Ukraine and the EU (1998) was based on the existing Agreement between the European Economic Community and the European Atomic Energy Community and the Union of Soviet Socialist Republics on trade and commercial and economic cooperation, signed on 18 December 1989. Currently, the Association Agreement (AA) provides a new legal framework for bilateral EU-Ukraine relations, replacing the out-dated PCA, after being ratified by all 28 EU Member States on September 1, 2017.

${ }^{3}$ The Ukrainian revolution got its name from the Maidan (Kyiv's Independence Square) where it started in February 2014.

${ }^{4}$ The second revision of the ENP in 2015 recognized that the attempts to create a "ring of friends" around the EU had failed and many of the neighbouring countries developed in the opposite way.
} 
overall analysis is helpful in articulating a number of factors that can form the basis for future cooperation between Ukraine and the EU.

\section{Literature Review}

The literature on Europeanisation (including EU governance) suggests that the EU exerts important transformative power outside its borders. In the post-Cold War context, the "Wider Europe" concept clearly presented the EU as a new kind of international actor (Commission of the European Communities 2003). The EU concept of Wider Europe, understood in progressive terms, implied increasing openness and inclusionary politics where neighbourhood relationships could be jointly negotiated between the EU and its regional partners. ${ }^{5}$ However, the "Arab spring" uprisings that commenced in 2010 clearly demonstrated that policy of the EU toward its neighbours had not lived up to its standards and required change (Biscop 2012). In light of regional conflicts and threats to the international order that seem to involve joint efforts by the international community in response, the European Commission (henceforth "Commission") called for a comprehensive EU approach to the management of external conflicts and crises. ${ }^{6}$ However, some scholars argue that the different objectives of the EU regional cooperation agenda have been mutually contradictory and contained both elements of potential regional partnerships and exclusionary and discriminatory aspects (Scott 2009; Liikanen, Scott, and Sotkasiira 2016).

Importantly, after the 2004 enlargement of the EU, and before the 2014 Ukraine crisis, Russia-EU relations had not reached a high priority on the agenda when brought for political discussion or dialogue. Andrey Makarychev claims that "the Russian version of neighbourhood has been an area predominantly marked by enmity and (geopolitical) competition," whereas the EU sees its neighbourhood as being a "ring of friends" converging progressively on "European values," which the EU naturally and hegemonically assumes to be its values (Makarychev in Emerson 2006, 1541). The EU was regarded as important to secure market access in Europe and attract foreign direct investments, but in terms of the EU foreign and security policy, Russia considered the United States, NATO, and the Organisation for Security and Cooperation in Europe as more important players (Haukkala 2003, 9).

While internally the EU's institutional development implied a shift towards coordinative network governance, externally it involved different forms of deep association towards neighbouring nonmember states (Lavenex 2008). The argument is that traditional rationalist, actor-based foreign policy approaches to the ENP that stress its weakness owing to the absence of accession conditionality may miss an essential part of EU external influence, according to which the ENP may be conceptualized as a "roof over expanding structures of sectoral, functional co-operation in Europe" (Lavenex 2008, 951). The EU has also paid considerable attention to regional reform (decentralisation), used in its broad sense to mean producing a change in the nature of relations

\footnotetext{
5 The EU launched the ENP in 2003 with the objective of avoiding the emergence of new dividing lines between the enlarged EU and its neighbours to the South and East, and of strengthening the prosperity, stability, and security of all countries concerned. The first revision took place in 2011 after the "Arab Spring" uprisings in many of the neighbouring countries participating in the ENP.

${ }^{6}$ The EU comprehensive approach towards crises is understood as providing security and building up a security community based on liberal democracy and a market economy, and not just management of the conflict itself.
} 
between national and subnational tiers of government (Mrinska 2010). Political developments since October 2013, when Ukraine decided against signing the EU-Ukraine Association Agreement (AA), once again stressed the need to pay serious attention to the social and institutional context when studying the EU's ability to function as an effective architect of its security community beyond its borders (Börzel and van Hüllen 2011; 2013; Papadimitriou, Baltag, and Surubaru 2017a; 2017b).

Similarly, the capacity of domestic actors to influence or defeat an illiberal government represents an important factor. As Langbein (2014) concludes in her research on regulatory convergence, beside strong EU policy conditionality, "multiplex" capacity-building that empowers various nonstate actors and state agencies leads to stronger convergence in Ukraine. EU actions target not only governments, but also various societal actors who either observe the EU's actions or cooperate with it. Academic debates emphasise that, in the absence of strong formal institutions, informal networks and decision-making play a crucial role (Solonenko 2015). Likewise, the mobilising effect of conditionality will be higher if society views EU conditions as legitimate (Schimmelfennig and Sedelmeier 2005; Vachudova 2005; Schimmelfennig 2009; Börzel and van Hüllen 2013). According to Burlyuk and Shapovalova, "conceptualisation of (EU) conditionality as a tool for societal mobilisation and differential empowerment of domestic actors" potentially explains domestic change as motivated by the EU (Burlyuk and Shapovalova 2017).

In addition to security matters, scholarly research claims that improved governance in the neighbourhood remains crucial to its economic growth (Aslund 2015). In Ukraine, the EU has provided consistent financial and political support to public administration reform (PA reform), a declared priority for all administrations since independence in 1991, regarded as central to country's democratic consolidation (Youngs 2009). Unsurprisingly, the role of the EU as an agent of change in its neighbourhood has been analysed profoundly. In the end, it is through EU assistance that understanding of EU norms and values by the government, civil actors, and society has been introduced and further reinforced in Ukraine. However, despite the current Ukrainian government being the most pro-reformist in the history of independent Ukraine, corruption and old-style bad governance continue to prevent the transformation and development of sustainable democratic institutions (Maksak 2015).

Moreover, critics of EU policies in Ukraine argue that linkages between the EU and EaP countries (even if increasing) do not necessarily translate into reform (Solonenko and Shapovalova 2011; Maksak 2015). According to Kataryna Wolczuk (2017) the problem is that many EU officials in Brussels and Kyiv are reluctant to promote change when engaging at the political level, believing that working with the current, pro-European administration is more desirable than triggering a change of government. Yet, Wolczuk argues that the most successful reforms so far have been those that created new institutions and systems in Ukraine - namely, a National Anti-Corruption Bureau, the electronic public procurement system (ProZorro), and the new road police. Furthermore, approaching the reforms as a technical process of legal approximation is insufficient for actual democratic transformation of the country (Wolczuk 2017). Likewise, the question remains whether EU policies and related actions are resulting in sustainable policy change in Ukraine. 


\section{Research Methods and Design}

The empirics of this paper rely on qualitative methods. The author conducted interviews in Kyiv, Lviv, and Krakow in 2014 and 2015 with governmental officials, academics, journalists, and NonGovernmental Organization (NGO) activists directly or indirectly dealing with ENP matters. Additional data was gathered through official (policy) documents, newspapers, and participation in the events related to the Ukraine crisis that took place both in Ukraine and at the international level during the same period and later. In order to answer the research question regarding the extent of the EU's transformative power in Ukraine, the paper draws on 1) the institutional arrangements governing Ukraine-EU relations, which mainly examine the EU's governance policy in the framework of the ENP and EaP; and 2) how these institutional arrangements are perceived and understood by different actors in Ukraine and abroad. Face-to-face and Skype interviews were conducted in English, Russian, and Ukrainian. All those interviewed were asked to reflect upon EU-related policies and programs in their field of activity and on the role that the Ukrainian government is playing in this process. While the interviews also covered other, more regional aspects of policy implementation which are not addressed here, the respondents were asked to assess 1) their relations with the EU, including EU institutions; 2) the role of the Ukrainian government; 3) activities of Ukrainian NGOs; and 4) their own role.

\section{The ENP: Review of EU Regional Programs and Instruments in Ukraine}

The Commission's "Communication on Wider Europe" proposed that the EU should aim to develop a zone of prosperity and a friendly neighbourhood - "a ring of friends" - with whom the EU enjoyed close, peaceful, and cooperative relations (Commission of the European Communities 2003). Drawing on that concept, the EU offered its "ring of friends" to share "everything but institutions." 7 The development of the ENP progressed further when, in 2009, upon the direct initiative of Sweden and Poland, the EU launched its Eastern Partnership policy (EaP). The EaP aimed to support six countries - Armenia, Azerbaijan, Belarus, Georgia, Moldova, and Ukraine in advancing to a market economy, sustainable development, and good governance. ${ }^{8}$ It was built on the framework of the ENP and designed to "accelerate political association and further economic integration" (Joint Declaration of the Prague Eastern Partnership Summit, 7 May 2009, 6 ) in several areas, including governance, trade, migration and border management, energy, and the environment between the EU and its partner countries.

This policy has been the first comprehensive initiative introduced into the system of the EU's external relations intended to help neighbouring countries with their approximation to and integration with EU rules and norms based on a differentiated approach, committed to permitting each partner country to progress in its own way and at its own speed. The EaP includes an official

\footnotetext{
${ }^{7}$ The quote is taken from a famous speech by Romano Prodi, former President of the European Commission: A Wider Europe-A Proximity Policy as the Key to Stability. "Peace, Security and Stability International Dialogue and the Role of the EU". Speech/02/619. Sixth ECSA-World Conference. Jean Monnet Project. Brussels, 5-6 December 2002, European Commission. Press release. http://europa.eu/rapid/press-release_Speech-02-619_en.htm. Accessed 10 May 2018.

${ }^{8}$ In Ukraine, implementation of the measures covered by previous Annual Action Programmes from the period 2007-2009 (European Commission 2011) was delayed pending timely confirmation of improved public financial management in the country, notably in the field of public procurement.
} 
package of at least three main elements that, if implemented, would significantly change relations between the EU and partner countries. First, the Association Agreement; ${ }^{9}$ second, a Deep and Comprehensive Free Trade Area (DCFTA), which aims to open markets and deal with competitiveness issues and standards set by the EU in the area of trade; and finally, full visa liberalisation. The AA highlights reforms in the spheres of justice, freedom, and security, particularly concerning provisions on mobility.

In addition, the EaP set up bilateral and multilateral projects and programs in areas of economic, political, and cultural development with all EaP participants (except for Belarus). ${ }^{10}$ EaP bilateral projects include Comprehensive Institution Building Programs (CIBP, CIB) which aim to help reform, develop, and improve the capabilities of the partner-states' public institutions. Since 2014, the CIB has been supported through the European Neighbourhood Instrument (ENI) ${ }^{11}$ that replaced the former European Neighbourhood Policy Instrument. Specific instruments like the Twinning, Technical Assistance and Information Exchange Instrument (TAIEX) ${ }^{12}$, and EU advisory missions have been used for the implementation of these programs. The EaP multilateral track similarly aims to foster links among partner-countries themselves. The Commission identifies four thematic platforms in the multilateral framework: 1) democracy, good governance, and stability; 2) economic integration and convergence with EU sectoral policies; 3) energy security; and 4) contacts among people. In the framework of these thematic platforms, five Flagship Initiatives have been launched: 1) integrated border management; 2) small and mediumsized enterprises facility; 3) regional electricity markets, energy efficiency, and renewable energy sources; 4) prevention, preparedness, and response to natural and man-made disasters; and 5) environmental governance.

The EaP's regional dimension has been covered by Pilot Regional Development Programmes inspired by the EU experience of cohesion policy. It supports regional development strategies by aiming at reducing disparities and funding projects, which help in overcoming structural deficiencies. In September 2011, the Committee of the Regions established a Conference of Regional and Local Authorities for the EaP as "a political body of multilateral cooperation"(2011). Moreover, Ukraine, as a member of the EaP, has benefited from EU cross-border cooperation, and

\footnotetext{
${ }^{9}$ In May 2012, the EU Council adopted three main conditions for the signature of the AA in Ukraine: conducting free and fair parliamentary elections, addressing cases of selective justice, and implementing reforms envisaged by the AA. The AA was negotiated between 2007 and 2011 and signed on 21 March and 27 June 2014. Substantial parts of its have been applied provisionally since 1 November 2014 and 1 January 2016 for the DCFTA. The AA in Ukraine fully entered into force only 1 September 2017 after it was ratified by all Member States of the EU. In June 2017 the visa liberalisation process was finalised. As of 11 June 2017, the visa obligation for citizens of Ukraine who hold a biometric passport and want to travel to the Schengen zone for a short stay was abolished (Migration and Home Affairs, European Commission, last update 19/04/2018).

${ }^{10}$ Belarus is excluded from the full participation in the EaP due to its violations of human rights and civic freedoms. However, in contrast to Russia, Belarus participates in the EaP, at least formally, for it to take part in its multilateral track. The Minsk Agreements and the lifting of most sanctions by the EU after the presidential elections in Belarus in February 2016 showed a slight warming of Belarus-EU official relations and opened perspectives for change in both Belarus itself and Belarus-EU relations.

${ }^{11}$ Interestingly, the ENI is funding cross-border cooperation programs in which Russia takes part under the ENP, even if it is not a part of the ENP as such.

${ }^{12}$ TAIEX supports public administrations with regard to the approximation, application, and enforcement of EU legislation as well as facilitating the sharing of EU best practices.
} 
various regional and inter-regional cooperation programmes, mainly in education (Tempus, Erasmus Mundus), transport and border assistance, institution building (TAIEX, SIGMA ${ }^{13}$ ), and investment. In addition, the Visegrad (also known as the "Visegrad Four" or simply "V4") ${ }^{14}$ countries have provided many forms of assistance to Ukraine and its people. As an example, Slovakia launched National Conventions for European Integration in Moldova and Ukraine and the Centre of Transfer of the Slovak Experience from the accession process at the Ministry of Foreign Affairs in Bratislava. In the end, such partnership activities endorse the development of good governing practices at the local and regional levels through the exchange of experience, ideas, and best practices in Ukraine.

Notably, the EaP initiative pays much more attention to civil society than previous EU policies towards its Eastern neighbourhood. It created the EaP Civil Society Forum, which included NGOs from both EaP countries and the EU. In addition to the Forum, the EuroNest Parliamentary Assembly (PA) ${ }^{15}$ was formed in May 2011 in Brussels. The 2011-2013 National Indicative Program (NIP) for Ukraine was adopted in March 2010 and had a budget of $€ 470.1$ million. The 2011-2013 NIP included a specific appropriation to finance new actions under the EaP, notably CIB with a minimum of $€ 43.4$ million and Cohesion Policy with a minimum of $€ 30.8$ million. Since the outbreak of the crisis in early 2014, it has mobilised a total of $€ 3.4$ billion in macrofinancial assistance (MFA) through three consecutive programmes of low-interest loans to Ukraine. That represented the highest amount ever made available by the EU to a non-EU country in such a short time. ${ }^{16}$ In addition to substantial financial assistance, the EU created the Support Group for Ukraine, which provided expert assistance for reforms. The Commission helped to organise the International Conference on Support for Ukraine in April 2015, while the Parliament launched a special mission to study the needs of Ukraine's parliament in the reform process. Overall, the Commission estimated the EU's financial assistance to Ukraine for 2014-2020 at €11 billion.

\footnotetext{
${ }^{13}$ Support for Improvement in Governance and Management (SIGMA) is a joint initiative of the Commission and the Organization of Economic Cooperation and Development, principally financed by the EU. It focuses on strengthening public management in areas such as administrative reform, public procurement, public sector ethics, anti-corruption, and external and internal financial control.

14 The V4 reflects the efforts of four Central European countries (Poland, Czech Republic, Slovakia, Hungary) to work together in a number of fields of common interest in the broader context of European integration, which prioritize the strengthening of the rule of law, the efficiency of national government and local governments, the transparency of public procurement, the reduction of state regulation, and the fight against corruption. Visegrad Fund.

15 The EuroNest PA consists of a European Parliament's delegation and the EaP's delegations from Armenia, Azerbaijan, Georgia, Moldova, and Ukraine (excluding official Belarus representation, but including participation of extra-parliamentary representatives of the opposition from Belarus). It aims to contribute to the strengthening, development and visibility of the EaP, as the institution responsible for "parliamentary consultation, supervision and monitoring."

${ }^{16}$ Information provided during the talk by David Stulik (press officer of the Commission representation in Kyiv, Ukraine) at the National Mohyla Academy. Key documents relating to MFA I (disbursed in 2014-15): Council decision of 12 July 2002 providing supplementary MFA to Ukraine ( $€ 110$ million); Decision of the European Parliament and of the Council of 7 July 2010 providing MFA to Ukraine ( $€ 500$ million); Memorandum of Understanding between the European Union and Ukraine for MFA for Ukraine of up to $€ 610$ million.
} 


\section{EU-Ukraine Territorial and Security Challenges}

The problem for Ukraine's sovereignty started with the collapse of the Soviet Union when Ukraine declared itself an independent state in 1991. That act pushed the borders of Russia further east and limited its access to the Black Sea. Ukraine signed the Charter on a Distinctive Partnership with NATO in 1997 and the Charter of the Organisation of Black Sea Economic Cooperation agreement in 1998, joined pro-European GUAM (Georgia, Ukraine, Azerbaijan, Moldova), and sought further development of its international relationships, aiming at membership in the World Trade Organisation (WTO) and NATO. ${ }^{17}$ Since independence, Ukraine has regarded cooperation with NATO as a priority for its national security. Hence, after the Orange Revolution, as a confirmation of its engagement with the Euro-Atlantic community, the coalition government of Viktor Yushchenko and Yulia Tymoshenko called for consideration of Ukraine's entry into NATO's Membership Action Plan (MAP) during the 2008 Bucharest summit. However, due to strong objections from Russia, the 26-member alliance was split, and thus confirmed it would not yet offer membership to Georgia or Ukraine. ${ }^{18}$

Ukraine is in an important geostrategic location between Europe and Russia. Russia perceived the plan of the Ukrainian government to join the MAP as an expression of undesired NATO's expansion to the east into its own sphere of geopolitical and economic influence (Ministry of Foreign Affairs of the Russian Federation). However, even within Ukraine, the application to join NATO in 2008 was met with opposition, which revealed the lack of an internal consensus of the political elites, as well as low public support at that time. ${ }^{19}$ In 2010 , the Ukraine government dropped plans for membership following the elections in which Viktor Yanukovych became the Ukrainian president. During Yanukovych's government, the Ukrainian parliament passed an initial draft of a bill, establishing Ukraine's non-aligned status on June 4, 2010. In 2014, Prime Minister Arseniy Yatsenyuk's government submitted to the Rada a draft bill that would cancel Ukraine's non-aligned status.

During 2014, Ukrainian territorial integrity and self-determination, based on general principles of international law and guided by subsequent multilateral and bilateral agreements, ${ }^{20}$ was challenged and undermined by the military conflict in its eastern territory and the annexation of Crimea by

\footnotetext{
${ }^{17}$ Ukraine became a member of the WTO on 16 May 2008. In the same year, Ukraine applied to join the NATO's Membership Action Plan (MAP).

${ }^{18}$ The paper does not provide detailed analysis of Russia's actions in the aftermath of the 2008 Bucharest summit due to its space limitations and its major focus on Ukraine-EU relations rather than Russia-EU relations. However, some facts of particular importance to Ukraine are covered in this paper.

19 This evidence is supported by opinion polls conducted in 2007 and 2008 by Razumkov Centre in Ukraine. The results of Razumkov Centre's sociological research are also published in the National and Security Defence magazine.

${ }^{20}$ Articles 2 and 3 of the Treaty on Friendship, Cooperation, and Partnership between Russia and Ukraine (signed in 1997) promised border recognition, removing all Russian territorial claims against Ukraine. The stumbling blocks of the Treaty were the division of the Black Sea Fleet and the federal status of Sevastopol. However, the Treaty contained guarantees that the two sides would build their relations on the non-use of force or the threat of force, “including economic means of pressure.” FBIS, doc. number FBIS-SOV-97-124.
} 
Russia. ${ }^{21}$ On 17 March 2014, following a highly-contested referendum, the Republic of Crimea declared its independence, started seeking recognition by the United Nations, and applied to join the Russian Federation. On the following day, Russia recognized Crimea as a sovereign state, an act condemned by the international community. This happened despite a 1994 Budapest agreement between the US, Russia, and the United Kingdom that provided Ukraine with security assurances in exchange for the dismantling and destruction of all its nuclear weapons. ${ }^{22}$ Thus, after the Ukraine crisis, the Russia-US/NATO relationship to some extent reverted to Cold War-style antagonism. That change was reflected at the NATO summit in September 2014 in Wales.

Likewise, relations between Russia and the EU have played a role in the development of instability in the Eastern neighbourhood region. The Foreign Policy Concept of the Russian Federation of 2000 stated that Russian foreign policy's first objective is to preserve and strengthen its sovereignty and territorial integrity, to achieve firm and prestigious positions in the world community, most fully consistent with the interests of the Russian Federation as a great power. Russia did not perceive the EU as a serious geopolitical partner, and the EU did not consider Russia to be an equal partner. Regrettably, the last EU-Russia summit, held in January 2014 in Brussels, demonstrated the complete dysfunction of the top-level EU-Russia relationship. ${ }^{23}$ In 2014 , after the Ukrainian revolution, the Russia-EU relationship was reduced to a technical level, its content consisting of managing conflicts over EU energy policies, Gazprom's operations in EU countries, and Russian gas transit across Ukraine (Trenin 2014).

The 2014 Ukraine crisis seriously tested the European security order with relation to its Eastern neighbourhood. As former Swedish Prime Minister Carl Bildt (2015) stated, it turned the EU's "ring of friends" into a "ring of fire." According to the 2016 Munich Security Report, Europe has failed to build a credible Common Foreign and Security Policy as envisaged by the Treaty of Lisbon, with institutional arrangements for decisive crisis management. However, if on the one hand, the Ukrainian crisis clearly exposed the vulnerability of the EU's foreign policy, on the other hand, it prepared Ukraine to acknowledge fully its geopolitical choice and foreign policy orientation towards Europe. The Maidan Revolution, the conclusion of the Association Agreement with the EU, and Russian aggression in eastern Ukraine dramatically changed not only the Ukrainian and European landscapes, but the whole international landscape.

In February 2015, the leaders of Ukraine, Russia, France, and Germany agreed to the so-called Minsk II accord concerning the conflict in the Ukrainian Donbas. This accord called for a ceasefire, withdrawal of heavy weapons from the front, release of hostages and detainees, changes in the Ukrainian constitution to give more autonomy to the regions, legislation on special status for parts of the Donbas regions of Donetsk and Luhansk, withdrawal of foreign forces from Ukraine, and restored Ukrainian government control over the eastern border by the end of 2015 (Ivan 2015). However, to date, this accord has achieved none of its goals. Additionally, the key diplomatic format to resolve the Ukraine crisis - the "Normandy group" - does not include the US. Hence,

\footnotetext{
21 The Crimean Constitution approved by Ukrainian Parliament in 1998 declared that the Autonomous Republic was "an inalienable component part of the Ukraine."

${ }^{22}$ As a result of this agreement, between 1994 and 1996, Belarus, Kazakhstan, and Ukraine gave up their nuclear weapons. Before that, Ukraine had the world's third largest nuclear weapons stockpile.

${ }^{23}$ Remarks by President of the European Council Herman Van Rompuy following the $32^{\text {nd }}$ EU-Russia summit, European Council, Brussels, 28 January 2014 EUCO 27/14 PRESSE 38 PR PCE.
} 
for the EU, how to deal with Russia in order to secure stability and security on its Eastern borders remains an open question.

\section{EU-Ukraine Institutional Challenges}

The 2014 Ukrainian crisis pressed the entire international community and powerful foreign actors to play an important role in shaping Ukrainian governing structures. Recall that Ukraine is a postcommunist country with a history of a highly centralised state and a state-owned economy. Moreover, the historical legacy of the Soviet culture of governance remains evident in various aspects of Ukraine's politics and public administration. The 2004 Orange revolution played a crucial role in determining the strategic direction of the Ukrainian policy towards its integration into the Euro-Atlantic community and democratic development (Kuzio 2006, Kubicek 2007, Haran 2013). However, subsequent domestic developments showed how fragile the gains of a democracy could be, if democratic changes are not institutionalized. Leaders of Ukrainian opposition started to fight with each other for power after 2005, keeping in mind the next presidential election scheduled to take place five years later.

The 2005 Blue Ribbon Commission report on Ukraine identified five key areas for national reform: political reform; social spending in areas such as health care and education; the tax system and the legal foundations of the financial system; a clear line to be drawn between the state and private enterprise, so that property rights are fully guaranteed; and integration into the world economy, to be facilitated through early accession to the WTO and closer integration with the EU. ${ }^{24}$ The report stated that the fundamental political problem in Ukraine, as in other post-communist countries, is that "the state rules its citizens, rather than serving them ...the state machinery must become efficient through real control by society and law" (The Blue Ribbon Commission Report 2005, 317). Thus, the focus of the political debate in Ukraine itself gradually shifted from geopolitical orientation to domestic reform.

The EaP initiative created a critical necessity to put into operation essential management structures to improve the quality of governance in its partners. Governance beyond EU borders is conceptualised here as the establishment of "institutions" (in the sense of organisations, but also of rules of the game), which define actors and their responsibilities, both in cooperation towards society's objectives and in resolution of conflicts that may arise. When talking about governance quality, this paper primarily means establishment of the rule of law, clear division of powers, control of corruption, and design of impartial and professional public administration. With the EU, Ukraine faced a very demanding roadmap, particularly in fighting organised crime and corruption (David Stulik. NaUKMA talk. Kyiv, 5 November 2014). The EU had been pushing Ukraine to adopt comprehensive reforms and, most importantly, to effectively implement anti-corruption provisions. Those reforms were intended to facilitate EU-Ukraine cooperation for the years to come.

\footnotetext{
${ }^{24}$ Integration into the EU has always been a priority for Ukrainian foreign policy. This goal has been supported by many political and legal instruments, such as the Program on the Integration of Ukraine to the EU (approved September 2000); the Law "On State Program of Adaptation of the Legislation of Ukraine to the Legislation of the European Union” (18 March 2004); and the EU-Ukraine Action Plan (2005).
} 
In 2010, after Viktor Yanukovych's arrival in power, Commissioner for the ENP Štefan Füle presented to the Ukrainian government the "Füle Matrix" 25 - a list of 18 political and economic reforms with benchmarks and deadlines. The document was intended to renew mutual commitments, as well as to bring clearer conditions for the finalisation of negotiations and eventual conclusion of the Association Agreement. On top of that, the EU promised some sectoral rewards, such as $€ 610$ million of MFA and $€ 2.5$ billion of credit for the modernisation of the Ukrainian gas transit system, conditional upon the implementation of the gas market reform. However, the lack of proficient $\operatorname{staff}^{26}$ and of local experience created additional challenges to reforms on the ground.

Yet, corruption remains the main obstacle to effective governance in Ukraine. According to the Corruption Perception Index (CPI), in 2006, Ukraine ranked 99 and scored 2.8 for perception of corruption, ${ }^{27}$ although, after the 2006 parliamentary elections, Ukraine was recognised as the only "free country" in the CIS in the ratings of Freedom House due to the accomplishments of the Orange Revolution, which were political freedoms, including freedom of the press, and free and fair elections. ${ }^{28}$ However, in 2010, Freedom House had to move Ukraine from the category of "free" country into "partially free". ${ }^{29}$ President Yanukovych (2010-2014), who rejected the EU agreement, had reconstructed the oligarchy, concentrating enormous wealth in his own family and dissatisfying both Ukrainian society and business (except, perhaps, his fellow oligarchs).

Ineffective (bad) governance ${ }^{30}$ in Ukraine happened to be the critical factor that caused the Maidan revolution in February 2014, in which people started to protest against the existing government. However, even after the revolution, oligarchs have continued to exercise significant influence through their control of the economy, much of the media, and the financing of political parties (Natalie Jaresko. The Fifteenth Annual Stasiuk Lecture in Contemporary Ukrainian Studies: "Ukraine in Transition," 24February 2017). In March 2015, President Petro Poroshenko dismissed Ihor Kolomoyskyi from the governorship of Dnipropetrovsk Oblast (region) after he attempted to assert control over the country's main oil company. At the same time, the Ukrainian government also sharply reduced energy subsidies, aiming to remove distortions in the market that exhausted state assets and encouraged corruption. However, despite the dismissal, Kolomoyskyi continued to influence politics through his support for election financing, his personal television network, armed battalions that are nominally loyal to the state, and other existing means.

\footnotetext{
25 Stefan Füle, European Commissioner for ENP. Exchange of views on South Caucasus and Ukraine. Speech/10/189. Committee on Foreign Affairs (AFET), European Parliament. Brussels.

${ }^{26}$ In 2015, after the EU conducted its second ENP revision in a reorganised EaP initiative, the "more for more" principle was further strengthened through a reformed CIB, providing more support in the form of expertise, twinning, technical assistance, and financial assistance.

${ }^{27}$ The CPI score relates to perceptions of the degree of corruption as seen by business people and country analysts. The CPI ranks countries and territories based on how corrupt their public sector is perceived to be. The 2006 index included 163 countries. The score ranged between 10 and 0 (highly corrupt). Transparency International.

${ }^{28}$ See the ratings of Freedom House, available at: https://freedomhouse.org/report/freedom-press/freedom-press2009? page $=251 \&$ year $=2009$.

${ }^{29}$ See Freedom in the world, 2011: The Authoritarian Challenge to Democracy. Washington, DC: Freedom House, 2011. www.freedomhouse.org/report/freedomworld/freedom-world-2011.

${ }^{30}$ I define "bad governance" as a form of governance involving practices such as abuse of human rights, corruption, lack of transparency, lack of responsiveness, and lack of accountability. In 2014, the CPI ranking in Ukraine shot up to 142 , and it subsequently scored 24 . The 2014 index included 175 countries and territories; the 2014 score ranged between 100 and 0 (highly corrupt). Transparency International.
} 
Persistent corruption among prosecutors and judges has been another important problem in Ukraine. In order to confront this problem, a package of anticorruption legislation adopted in 2014 has been implemented. The government set up a National Anticorruption Bureau (NABU) to investigate corrupt officials and a National Agency for Corruption Prevention (NACP), and also planned a separate anticorruption section within the prosecutor general's office. Yet, Ukrainian nongovernmental organizations focused on combating corruption criticized the government because they were not properly included in the process of choosing the new leaders of the NACP as required by law. In December 2015, President Poroshenko signed a law ${ }^{31}$ creating an additional agency to deal with the assets of corrupt officials (Freedom House Report on Ukraine, 2016). In addition, despite all these reforms, Poroshenko did not give up his control of the judicial branch.

Importantly, due to and during the Ukrainian crisis, a strong civic identity developed in Ukraine partly owing to institutional cooperation with the EU on various levels. The EU regional partnership has consistently grown through its social engagement in various regions of Ukraine (Maryan Manko. Interview. Lviv, 4 November 2014). It has been due to civil society pressure, coupled with external pressure from the EU and international donors, that governance reforms have been initiated in Ukraine in the first instance. A pro-European orientation, together with the growth of civic identity and patriotic feelings, have helped create a political nation in Ukraine (Papadimitriou et al. 2017a; 2017b). During 2015 and 2016, however, Ukrainian citizens were disappointed with the government's slow progress in combating corruption. Civil society activists wanted the EU to play a stronger political role in bringing about change in Ukraine.

\section{Conclusion}

This paper examined the extent to which the EU's ENP has managed the crisis that began in Ukraine in 2013-2014. It aimed to understand why the EU was unable to prevent a conflict on the ground: why was the relationship between the EU and Ukraine fairly unsuccessful at promoting stability in the region, and in Ukraine in particular? What had been missing in the EU policy in Ukraine that rendered it unable to prevent a conflict on the ground? It provided a summary of the territorial and security challenges, which can be used to identify institutional opportunities for effective cooperation between Ukraine and the EU. In the end, this study means to contribute to debates in the literature on EU governance and its foreign policy in the Eastern neighbourhood.

The EU's persistent presence in Ukraine pushes the country towards its institutional development and the implementation of an important number of reforms, including much-needed anticorruption provisions, while building a security community on its borders. However, the adoption of the ENP and EaP further intensifies Russian concerns in the shared neighbourhood. Regrettably, to this date, Russia and the EU have not developed a full understanding of each other's positions and priorities. While uneven development without the promise of EU membership limits the implementation of any "innovative policy framework" in Ukraine, the revised ENP seems to orient Ukraine more toward a form of democratic development, which can be created within its own society by using EU mechanisms and tools. The review of the challenges and opportunities reveals that the EU provides Ukraine with exceptional support for its long-term transformation and the establishment of a democratic system and effective governance. Academic and policy research

\footnotetext{
${ }^{31}$ However, according to experts, the law potentially exacerbated the problem of overlapping authorities.
} 
also show that EU cooperation with Ukraine depends on negating asymmetric relations and applying the EU soft power concept on the ground responsibly and respectfully. 


\section{References}

Aslund, Anders. 2015. Ukraine: What Went Wrong and How to Fix It? Peterson Institute for International Economics. Washington DC.

Bildt, Carl. 2015. “The Fire Forging Europe.” Project Syndicate. The World's Opinion Page.

Biscop S. 2012. "The ENP, Security, and Democracy in the Context of the European Security Strategy" in Whitman, R. G. and Wolff, S. (eds.) The European Neighbourhood Policy in Perspective. Basingstoke: Palgrave MacMillan.

The Blue Ribbon Commission Report. 2005. Proposals for the President: A New Wave of Reform. UNDP Ukraine.

Börzel, Tanja A., and Vera van Hüllen. 2011. "Good Governance and Bad Neighbors? The Limits of the Transformative Power of Europe". KFG Working Papers. No.35, December.

Börzel, Tanja A., and Vera van Hüllen. 2013. The EU's Governance Transfer: From External Promotion to Internal Protection. SFB-Governance Working Paper Series. No.56.

Burlyuk, Olga, and Natalia Shapovalova. 2017. "'Veni, Vidi, ... Vici?' EU Performance and Two Faces of Conditionality towards Ukraine.” East European Politics 33 (1): 36-55.

Commission of the European Communities. 2003. Communication from the Commission to the Council and the European Parliament: "Wider Europe - Neighbourhood: A New Framework for Relations with our Eastern and Southern Neighbours.” COM(2003)104 final, Mar 11. Brussels.

Committee of the Regions. 2011. "Local and Regional Government in Ukraine and the Development of Cooperation between Ukraine and the EU." Luxembourg, CoR $173 / 2010$.

Emerson, M. 2006. The Elephant and the Bear Try Again: Options for a New Agreement between the EU and Russia. Centre for European Policy Studies, Brussels.

ENP Package. 2012. Country Progress Report - Ukraine, MEMO/12/344. Brussels.

Freedom House. 2016. Freedom in the World 2016. Ukraine. Report.

Haran, Olexiy. 2013. Ukraine: Pluralism by Default, Revolution, Thermidor. Russian Social Science Review 54 (3): 68-89.

Haukkala, Hiski. 2003. A Problematic Strategic Partnership', in: Dov Lynch (ed.), EU-Russian Security Dimensions. Paris: European Union Institute of Security Studies, pp.8-19.

Ivan, Paul. 2015. "The Ukraine Crisis and the Demise of the European Security Order." Policy Brief. European Policy Centre.

Kubicek P. 2007. Ukraine and the European Neighbourhood Policy: Can the EU help the Orange Revolution Bear Fruit. East European Quarterly XLI (1):1-24.

Kuzio, Taras. 2006. "The Orange Revolution at a Crossroads.” Demokratizatsiya 14 (4): 477492. 
Langbein, Julia. 2014. "European Union Governance towards the Eastern Neighbourhood: Transcending or Redrawing Europe's East-West Divide?” JCMS: Journal of Common Market Studies 52 (1): 157-174.

Lavenex, Sandra. 2008. “A Governance Perspective on the European Neighbourhood Policy: Integration Beyond Conditionality?” Journal of European Public Policy 15 (6): 938-955.

Liikanen, Ilkka, James W. Scott, and Tiina Sotkasiira. 2016. The EU's Eastern Neighbourhood: Migration, Borders and Regional Stability. Routledge Series on Russian and East European Studies.

Maksak, Hennadiy. 2015. "Focus on Ukraine / Eastern Partnership Revisited." Associated Countries in Focus. The Stefan Batory Foundation, FES Representation in Poland, Warsaw.

Ministry of Foreign Affairs of the Russian Federation, http://www.mid.ru/en/main_en, accessed 13 July 2018.

Mrinska, X. 2010. Between Confusion and Ignorance: Public Policy Responses to Growing Regional Divergence in Ukraine. Annual Conference of the Regional Studies Association, Pecs, Hungary, 2010. Unpublished Paper.

On the Principles of Domestic and Foreign Policy: The Law of Ukraine from 01.07.2010 №2411-VI // [Electronic resource]. Access: http://zakon.rada.gov.ua.

Papadimitriou, Dimitris, Dorina Baltag, and Neculai-Cristian Surubaru. 2017a. "Introduction: Assessing the Performance of the European Union in Central and Eastern Europe and in its Neighbourhood." East European Politics 33 (1): 1-16.

Papadimitriou, Dimitris, Dorina Baltag, and Neculai-Cristian Surubaru. 2017b. Special Issue: Assessing the Performance of the European Union in Central and Eastern Europe and in its Neighbourhood East European Politics 33 (1): 1-142.

Sasse, Gwendolyn. 2008. "The European Neighbourhood Policy: Conditionality Revisited for the EU's Eastern Neighbours.” Europe-Asia Studies 60 (2): 295-316.

Schimmelfennig, Frank. 2009. "Europeanisation Beyond Europe." Living Reviews in European Governance 4 (3): 1-28.

Schimmelfennig, Frank, and Ulrich Sedelmeier. 2005. The Europeanization of Central and Eastern Europe. Ithaca: Cornell University Press.

Scott, James W. 2009. "Bordering and Ordering the European Neighbourhood: a Critical Perspective on EU Territoriality and Geopolitics." TRAMES 13(63/58) (3): 232-247.

Solonenko Iryna. 2015. "Ukrainian Civil Society from the Orange Revolution to Euromaidan: Striving for a New Social Contract." in Institute for Peace Research and Security Policy at the University of Hamburg/IFSH (ed.), OSCE Yearbook 2014, Baden-Baden, pp. 219235.

Solonenko, Iryna and N. Shapovalova. 2011. "Is the EU's Eastern Partnership promoting Europeanisation?", FRIDE Policy Brief. 
Trenin, Dimitri. 2014. "The Ukraine Crisis and the Resumption of Great Power Rivalry." Paper. Carnegie Moscow Center.

Youngs, Richard. 2009. “Democracy Promotion as External Governance?” Journal of European Public Policy, 16 (6): 895-915.

Vachudova, Milada Anna. 2005. Europe Undivided: Democracy, Leverage, and Integration after Communism. Oxford: Oxford University Press.

Wolczuk, Kataryna. 2017. "EU Must Be Bolder in Driving Reforms in Ukraine.” Expert Comment. Chatham House. The Royal Institute of International Affairs.

\section{Interviews and Talks}

Chłoń, Tomasz. Senior Officer. NATO Public Diplomacy Division. Talk at the Conference "Ukraine's Transformation: Assessments and Solutions". Chatham House. London, UK. 5 July 2017.

Consulate General of Ukraine in Krakow. Poland. Talk with the Consul. 13 December 2014.

Jaresko, Natalie. Former Finance Minister of Ukraine (2014-2016). The Fifteenth Annual Stasiuk Lecture in Contemporary Ukrainian Studies: "Ukraine in Transition". Cambridge, UK. 24 February 2017.

Kedzierski, Marcin. Director at the Club Jagielloński. Dyrektor Programowy Centrum Analiz at Klub Jagielloński. Assistant Professor at Uniwersytet Ekonomiczny w Krakowie. Interview. Krakow. 12 December 2014.

Khodakivsky, Sashko. Student at the History Department of the National University of "KyivMohyla Academy" (NaUKMA). Interview. Kyiv, Ukraine. 5 November 2014.

Klympush-Tsintsadze, Ivanna, Vice-Prime Minister for European and Euro-Atlantic Integration, Ukraine. Talk at the Conference "Ukraine's Transformation: Assessments and Solutions”. Chatham House. London, UK. 5 July 2017.

Manko, Maryan. Researcher in Economy and Culture Management in Lviv. Interview. Lviv, Ukraine. 4 November 2014.

Member of the European Youth Parliament. Ukraine. Interview. Kyiv, Ukraine. 6 November 2014.

Member of a Communication Team. State Office of the European Coordination and EuroAtlantic Integration. Association4U Project. Skype Interview. 2 June 2015.

Romanova, Valentyna. Senior Expert at the Institute for Strategic Studies "New Ukraine". Kyiv. Skype Interview. 4 June 2015.

Specialist. Department of International Technical Aid and International Cooperation. Regional State Administration, Lviv. Interview. 4 November 2014.

Stulik, David. Press Officer. EU Delegation to Ukraine. Talk at the National University of "Kyiv-Mohyla Academy" (NaUKMA). Kyiv, Ukraine. 5 November 2014. 
Published by the Centre for European Studies at Carleton University, Ottawa, Canada Available online at: journals.carleton.ca/rera/index.php/rera

RERA is an open-access electronic academic double-blind peer-reviewed journal. Topics relate to the European Union, its Member States, the former Soviet Union, and Central and Eastern Europe. The journal is a joint project of the Institute of European, Russian and Eurasian Studies (Carleton University) and its associated research unit, the Centre for European Studies. RERA aims to provide an accessible forum for research, to promote high standards of research and scholarship, and to foster communication among young scholars.

RERA aims to provide an accessible forum for research, to promote high standards of research and scholarship, and to foster communication among young scholars.

\section{Contact:}

Carleton University

The Centre for European Studies

1103 Dunton Tower

1125 Colonel By Drive

Ottawa, ON K1S 5B6

Canada

Tel: +01 613 520-2600 ext. 3117; E-mail: rera-journal@ carleton.ca

\section{Creative Commons License}

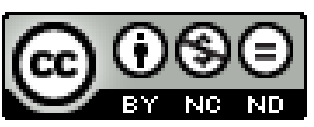

creativecommons.org/licenses/by-nc-nd/3.0

This Working Paper is licensed under a Creative Commons Attribution-Non-CommercialNo Derivs 3.0 Unported License (CC BY-NC-ND 3.0).

Articles appearing in this publication may be freely quoted and reproduced, provided the source is acknowledged. No use of this publication may be made for resale or other commercial purposes.

ISSN: $1718-4835$

(C) 2018 The Author(s) 